The Journal of International Lingual, Social and Educational Sciences Year: 2019, Volume: 5, Number: 1

DOI:10.34137/jilses.572963

Geliş Tarihi: 31.05.2019

Kabul Tarihi: 10.07.2019

Makale Türü: Araştırma Makales
Received: 31.05 .2019

Accepted: 10.07.2019

Research Type: Research Article

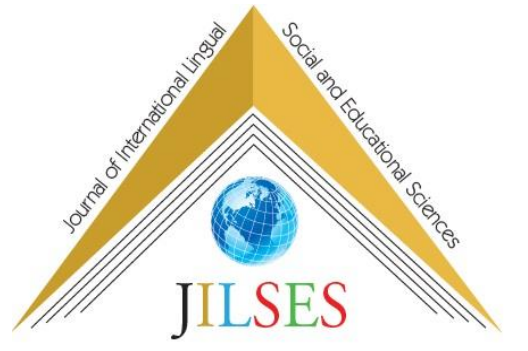

\title{
Knidos Hellenistik Ev Duvar Resmi ${ }^{1}$
}

\section{Fuat Yılmaz ${ }^{2}$ Kudret Demiröz $z^{3}$}

$\ddot{O ̈ z e t}$

Hellenistik Dönem Resim sanatına ait bilgiler birkaç örnek dışında ancak antik kaynaklar ile sinırlıydı. Son yıllarda ortaya çıkartılan duvar resimleri bu konudaki bilgilerimize katkılar sunmaktadır. Bunlar arasında Makedonya'daki mezar resimleri, Delos adası, Kıbrıs Baf boyalı kaya mezarl, Pergamon, Miletos, Erythrai, Priene ve Knidos duvar resimleri saylabilir. Anadolu'nun güneybatısında Muğla'nın Datça İlçesinde yarım ada üzerinde yer alan Knidos antik kentinde açığa çıkartılan Hellenistik evde ele geçen fresk parçaları Hellenistik Dönem Anadolu fresk sanatı için önemli bilgiler sunmaktadır. Klsmen 3 metreye kadar korunmuş olan fresklerin Pommpei 1. Stilde olduğu gibi hem plastik hem de boyama olarak duvar örgüsü şeklindedir. Ancak burada Pompeii'den farklı olarak duvar örgüsü arasında üç boyutlu boyanmış bordürler ve figür bezemeli bir friz yer almaktadır. Bu frizde Akhilleus'un Kherion tarafından eğitilmesi konusu işlenmiştir. Benzer örneklerden de yola çıkarak bu resimlerin tarihini M.Ö. 2. Yüzyılın 2. Yarısına vermek mümkündür.

Anahtar Kelimeler: Anadolu, Hellenistik Dönem, Konut mimarisi, Fresk, Knidos

\section{Hellenistic Wall Painting From Knidos}

\begin{abstract}
What we know about Hellenistic period painting art is restricted with the ancient sources except a few example. Wall paintings that were uncovered in recent years, contributed information about this field. Among these examples, they are tomb paintings in Macedonia, Delos Island, Cyprus Paphos painted rock tomb, Pergamon, Miletos, Erythrai, Pirene and Knidos wall paintings. In the southeast of Anatolia a Hellenistic house found in Knidos ancient city, located in Datça district of Muğla consisting of fresco art pieces gives important information about Hellenistic period Anatolian fresco art. Those preserved nearly $3 \mathrm{~m}$ long fresco art samples were like Pompeii 1 style both plastic and painting masonry. Different from Pompeii this masonry has three-dimensional painted bordures and figures decorated frieze. This frieze demonstrates Achilleus being educated by Kherion. Based on similar examples it can be said that these paintings date back to the second century's second half.
\end{abstract}

Keywords: Anatolia, Hellenistic period, Residential architecture, Fresco, Knidos

\footnotetext{
${ }^{1} \mathrm{Bu}$ makale Uluslararası Asos Congress'de (Antalya Alanya, 2019) sunulan sözlü bildirinin genişletilmiş halidir. Bu çalışma 30. 09. 2013 tarih ve 2013/5387 sayılı Bakanlar Kurulu Kararı ile Kültür ve Turizm Bakanlığı ve Selçuk Üniversitesi adına sürdürülen Knidos Kazı ve Araştırmaları kapsamında ve Knidos Kazı Başkanlığı'nın izni ile yapılmıştır. Ayrıca bu makale Selçuk Üniversitesi, Bilimsel Araştırma Projeleri Koordinatörlüğü (BAP), 19203001 nolu "KNIDOS HELENISTIK EV DUVAR RESIMLERİ” adlı proje ile desteklenmiştir.

${ }^{2}$ Dr. Öğretim Üyesi, Trakya Üniversitesi, fuatyilmaz@trakya.edu.tr, http://orcid.org/0000-0002-0677-0028

${ }^{3}$ Yüksek Lisans öğr., Selçuk Üniversitesi, kudretdemiroz42@gmail.com, https://orcid.org/0000-0002-4179-1043
} 


\section{Giriş}

Yaklaşık M.Ö. 4. Yüzyıldan M.Ö. 1. Yüzyıla kadar olan dönem Hellenistik Çağ olarak adlandırılmıştır. Büyük İskender'in seferleriyle başlatılan bu dönem özellikle sanatın etnik ve coğrafi sınırları aştığı bir dönemdir. Balkanlardan başlayarak Kıta Yunanistan, Anadolu, Levant, Mısır ve hatta Hindistan'a kadar olan coğrafyayı içine almaktadır. Tüm Akdeniz'i kapsayan ortak bir kültür Mısır'dan Makedonya'ya kadar uzanmakta, Coğrafyanın en uzak noktalar arasındaki etkileşimini göstermektedir.

Makedonya kralı II. Philippos'un başlattığı ve Büyük İskender'in devam ettirdiği Hellenlerin lideri olma hayali başarılı olmuş ve yeni bir çağ açılmıştır. Büyük İskender, seferine başladığı M.Ö. 334 yılından M.Ö. 323 yılındaki ölümüne kadar geçen sürede Anadolu'yu, Mısır'1, Suriye'yi, Pers imparatorluğunu ve Kuzey Batı Hindistan'1 fethetti. Büyük İskender'in kurduğu imparatorluk ölümünden sonra Komutanları arasında bölüşülmüss, Hellenistik krallıklar Dönemi M.Ö. 31 yılında Ptolemaios Hanedanlığının, Actium Savaşında Roma İmparatorluğuna yenilmesiyle son bulmuştur.

Hellenistik Dönem Resim sanatına ait bilgiler ancak antik kaynaklar ile sınılıydı (Plinius, Nat. Hist. Kitap XXXV). Resim sanatını anlayabilmek için çok az sayıda ele geçen resim örneklerini yanı sıra mozaikler, vazo resimleri ve küçük objelerden de faydalanmak gerekmektedir. Ayrıca Roma duvar resmine yansıyan Hellenistik öğeler bize resim sanatı hakkında ipuçları vermektedir.

Son yıllarda ortaya çıkartılan Hellenistik Döneme tarihlenen duvar resimleri bu konudaki bilgilerimize katkılar sunmaktadır. Bunlar arasında Makedonya'daki mezar resimleri (Drougou 2005), Delos adasındaki resimler (Bezerra de Meneses 1984, 77-88), Kıbrıs Baf (Пó 2017, 207-330; Andreas 1988, 125), Miletos (Weber 2005, 144), Erythrai (Bingöl 1997, 88-97), Priene (Rumscheid 2000, 140-150) ve Knidos (Love Jan. 1972) duvar resimleri ikonografi ve stil açısından önemli bilgiler sunmaktadır.

\section{Yöntem}

$\mathrm{Bu}$ aşamada evin yapısı, tarihi, freskin stili incelenmiş ve birçok kaynak ve örnekten yola çıkılmıştır. Aynı zamanda çağdaşı fresk modelleri incelenerek geçerli verilere ulaşılmaya çalışılmıştır. Makalenin hazırlanmasında izlenilen yöntemler materyal arazi ortamında değerlendirilmiştir. Helenistik evin konumu, var olan depo odaları, bulunan freskin mitolojideki yeri ve önemi, işlenen konu ve yapıldığı tarih veya dönemi hakkında kaynaklardan ve konu hakkında uzman olan kişilerden de yardım alınarak kronolojisi incelenmiş ve bu şekilde sağlıklı verilere ulaşılıp çalışma oluşturulmuştur.

\section{Bulgular ve Yorumlar}

Yapılan çalışma sonucunda resim veya fresk sanatının Batı Anadolu'daki kronolojisi ve freskin Anadolu'daki yeri, kronolojideki yeri incelenip; Anadolu'da fresk konusundaki önemli bir boşluk doldurulmaya çalışılmış ve 1. Stil olan tarza ek olarak hikayeci bir anlatımında işlenmiş olmasına dikkat çekilecektir.

\section{Knidos'un Yeri ve Kazı Tarihçesi}

Knidos antik kenti (resim 1) konum olarak Anadolu'nun güneybatısında Muğla'nın Datça İlçesinde yer almaktadır (Doksanaltı 2006, 1 vd.; Doksanaltı 2018, 5 ve Bruns-Özgan 2002, 3). Antik kent üç tarafinın denizle çevrili olmasından dolayı yarım ada şeklindedir, $63 \mathrm{~km}$. uzunluğundaki bu yarım ada Ege ve Akdeniz'in birleşme noktasında bulunmaktadır (Bruns-Özgan 2002, 3). Ayrıca yarım adaya bağlı durumda küçük bir adacık bulunmakta ve Kap Krio veya Deve Boynu adıyla anılmaktadır. Kentin önemli bir bölümü anakaraya yerleşmiş durumda idi (Doksanaltı 2006, 1). Günümüze kadar ulaşmış zamana meydan okumuş olan yapılarıyla ve birçok müzede bulunan eserleriyle Knidos'un önemli bir merkez olduğunu söylemek mümkündür ve bu önemini sanat, kültür ve ticaret kollarında ayrı ayrı göstermektedir.

C. Thomas ve R. Murdoch Smith tarafindan, Royal Engineer maddi katkılarıyla British Museum için 1858-59 yılları arasında yapılan kazılar Knidos'taki birinci dönem kazılarıdır. Knidos'un şehir planı bu kazıyla ortaya çıkarılmış, yapılan kazılar ve çalışmalar yayınlanmıştır. Kazı ve yayın çalışmalarının 1. Dönemi, Demeter kutsal alanı, Korinth Tapınăğ, Gymnasium, küçük tiyatro, Nekropol alanı ve Kap Krio alanlarını kapsamıştır (Doksanaltı 2006, 1).

Arkeolojik kazılar dışında, 19. Yüzyıl ve 20. Yüzyıl başlarında Batılı gezginlerin ziyaretlerini anlattıkları yayınlarda da Knidos'a yer verdikleri görülür. Knidos'un Hippodamik planda inşa edildiğinden söz eden F. Krischen ve A. von Gerkan 1913 yılında bölgeyi ziyaret etmiştir. M.Ö. 4. Yüzyılla tarihlenen cadde ve teras sistemiyle şehir planı söz konusu ziyaretçiler tarafından yayınlanmış (Krischen 1913, 476; Gerkan 1924, 92-98) 
ve kazı yapılması planlanmış ancak 1. Dünya savaşının başlamasıyla burada yapılması planlanan kapsamlı kazı çalışması iptal olmuştur.

1967 yılında ikinci dönem kazısı C. I. Love başkanlığında başlamıştır. Long Island Üniversitesi adına yapılan bu kazıda ise caddelerin bir kısmı Hellenistik ve Roma Dönemi konutlar, üst terasta bulunan Aphrodite veya Yuvarlak Tapınak, Dionysos “küçük tiyatro" ve Apollon tapınakları, Bizans kilisesi ortaya çıkarılmıştır. 1977'de kazı durdurulmuş ve kazı sonuçları yayınlanmamıştır.

Üçüncü dönem kazısı ise 1987 de Eski Eserler ve Müzeler Genel Müdürlüğü adına o dönemde Selçuk Üniversitesi'nde görev yapan Prof. Dr. Ramazan Özgan tarafından başlatılmış (Doksanaltı 2006, 19-22) ve 2006 yılında son bulmuştur (Doksanaltı, Karaoğlan, Tozluca 2018, 25).

Dördüncü dönem ise 2012'de Müzeler Genel Müdürlüğü adına halen Selçuk Üniversitesi’nde görev yapan Bölüm Başkanı Prof. Dr. Mustafa Ertekin Doksanaltı kazı başkanlığında başlamıştır ve günümüzde hala devam etmektedir (Doksanalt1, Karaoğlan, Tozluca 2018, 26).

\section{Knidos Hellenistik Ev Mimarisi ve Duvar Tekniği}

Kentin limandan gidildiğinde yukarıda kalan teraslara giden caddeye paralel olan merdivenli yol yanında açığa çıkan bir konut alanı bulunmaktadır (resim 2-3). Hellenistik ev kente ulaşımı sağlayan karayolunun hemen yukarısında kalmaktadır. Söz konusu evin Roma Dönemine ait başka bir evle yan yana bulunması evin uzun süre kullanılmış olduğu olasılığını akla getirmekte, Hellenistik evde bulunan bir sütun ise evin sütunlu bir bahçesi olduğunu düşündürmektedir.

Hellenistik ev büyük bir ihtimalle bir villa idi. Bulunan bölüm ise evin bodrum katı görevini gören zemin katı olmalıdır. Hellenistik evin dış cephe duvarları örme tekniği karışık duvar tekniğiyle yapılmış ve konglomera ve kireçtaşı blokları kullanılarak inşa edilmiştir. Yapının iç kısımları ise gri kireç taşı ve yine konglomera bloklarından oluşmaktadır. Bu temel duvarlar daha iyi korunmuş şekilde olup üzerinde yükselen duvarlar kerpiç duvarlardır (resim 4). Buna paralel olarak devam eden yatay harç tabakası koyu renkli olup daha parlak olan kerpiç tabakasından belirgin olarak farklılık göstermektedir (Love 1970, 66 vd.; Bruns-Özgan 2002, 87-88). Kerpiç duvar tekniği çok eski zamanlardan beri bilinen ve kullanılan bir teknik olmuştur. Bu tekniğin kullanılma sebebi Hellenistik ve Roma dönemlerinde ekonomik açıdan daha uygun olmasıdır. Knidos’ta olduğu gibi diğer yapı malzemelerinin az olduğu yerlerde de bu tekniğe çok fazla başvurulmuş ve kullanılmıştır (Bruns - Özgan 2002, 87-88). Knidos’ta bulunan Hellenistik evin kerpiç duvarları sıvayla düz bir zemine dönüştürülmüş ve hatta sıvalı yüzeyin üstü kazıma tekniği çizimlerle süslenmiştir (Love 1970, 66 vd.; Bruns- Özgan 2002, 87 vd.). Üst katı yıkılmış olan Hellenistik evin duvarları bodrum katına yığılmış ve bodrum katı terasın alt bölüm kısmı haline gelmiştir ve büyük bir şans olarak üst kata ait bezemeli sıva parçaları kazılar esnasında tekrar gün yüzüne çıkarılmış; daha sonra bulunan parçaların rekonstrüksiyonu yapılmıştır (Love 1971, 6-8). Bu parçalar alçı sıvalı ve fresklerden oluşmaktadır. Bu durum bize Hellenistik evin görkemini ve ihtişamını kanıtlar niteliktedir. Elde edilen freskler Bodrum Müzesi'ne nakledilmiş ve müzede bazı bölümleri restore edilmiştir (Love 1970, 66 vd.; Bruns-Özgan 2002, 87-88).

\section{Knidos Hellenistik Ev Duvar Resimleri}

Knidos Hellenistik evin 3 metreye varan duvarları stükko ile plastik silmelerle dekore edilmiş ve fresk tekniğinde oldukça renkli boyanmıştır ${ }^{4}$. Duvarın alt kısmında orthostat seviyesinde kare paneller yer alır. Onun üzerinde ise tek sıra halinde dikdörtgen formlu duvar örgüsü, bordür kuşaklarının çevrelediği figürlü mitolojik sahne yer almaktadır. En üste ise tekrar tek sıra halinde dikdörtgen formlu duvar örgüsü yer alır (resim 5).

Orthostatın üzerinde yer alan duvar örgüsü alttan ve üste örgü motifiyle sınırlandırılmıştır. Bunun üzerinde ise sarı, beyaz, kahverengi renklerde üç boyutlu olarak yapılmış kırık meander bandı yer alır. Üç boyutlu meander bandının hemen üzerinde yine üç boyutlu yapılmış kırmızı zemin üzerine, kahverengi-krem tonlarda yumurta-ok dizisi vardır. Bunun üzerinde ise, duvarın ana bezeme kuşağı olan figürlü kompozisyonun yer aldığı friz bulunur. Burada siyah zemin üzerine renkli insan figürlerinin yer aldığı mitolojik bir konu betimlenmiştir. Bu bandı üstte yine üç boyutlu olarak yapılmış kahverengi-krem tonlarında örgü motifi sınırlar. Bordürün üzerinde ise ters akantus (resim 6) ve rankeler arasında Eros, kuş, çekirge gibi figürlerin olduğu betimlemeler bulunmaktadır

\footnotetext{
${ }^{4}$ Duvar üzerine yapılan resimler yapım teknik açıdan Buon fresco ve Fresco Secco olarak adlandırılır. Basit anlamda 1slak sıva üzerine yapılan resimlere Buon Fresco yada kısaca Fresko denir. Bu teknikte Kireç sıvası kurudukça pigmentler alttaki sıvaya yapışır ve renkler sıvaya iyice temas edip bütünleşerek kurur, kalıcı bir sıva tabakası oluştuğundan resim çok daha sağlam ve dayanıklı olur. Fresco Secco yada kısaca secco ise sıva kuruduktan sonra yapılan resimlere denir. Burada pigmentler bir bağlayıcı ile karıştırılarak sıvanın yüzeyine uygulanmaktadır. Bu konuda detaylı bilgi için bakınız: Yılmaz, F. (2012). “Antik Dönemde Fresk Yapım Teknikleri”. Trakya Üniversitesi Edebiyat Fakültesi Dergisi, Cilt 2. Sayı:4 ,95-105.
} 
(resim 7). Friz üst kısmı kahverengi - krem renklerinde üç boyutlu meander bordürü ile sınırlandırılmıştır (Love 1971, 6-8).

Freskin ana bezeme kuşağı olan figürlü frizde mitolojik bir konu işlenmiştir (resim 8). Burada Akhilleus'un Kenthauros Kherion tarafından eğitilmesi anlatılmaktadır. Kalabalık bir kompozisyona sahip olan frizin korunma durumu iyi değildir. Friz her iki uçtan da mermer taklidi pano ile sınırlandırılmıştır. Frizin en solunda ilk figür mavi renk bir khiton giymiş ayakta duran bir kadın figürüdür (resim 9). Bu figürden sonra oturur durumda ikinci bir başka figür ile ayakta duran üçüncü bir kadın figürü vardır. Oturur durumdaki dördüncü figür olasılıkla bir erkektir. Beşinci figür de oturur pozisyondaki bir kadındır. Frizin ortasında yer alan altıncı figür Kherion'dur. Yedinci figür ise kalan izlerden anlaşıldığı üzere küçük bir çocuk olarak betimlenen Akhilleus olmalıdır. Kherion ve çocuk figürü arasında ne olduğu anlaşılamayan bazı lekeler korunmuştur. Bunlardan sonra ayakta bir kadın, oturan bir kadın figürü kısmen anlaşılabilmektedir.

Kompozisyonun ortasında yer alan Akhilleus ve Kherion'un çevresindeki diğer figürler büyük ihtimalle Akhilleus'un annesi Thetis ve babası Peleus olmalıdır. Diğer figürler ise Musaları tasvir etmektedir. Zemin koyu renkte, figürlerin canlı renklerle yapılması insanda bir canlılık hissi ve büyüleyici bir etki yaratmaktadır. Knidos’ta Hellenistik ev üzerinde bulunan terasta zengin süslemelere sahip başka evlerin de bulunması ayrıca dönemin zenginliğini göstermektedir (Bruns- Özgan 2002, 90-91).

Knidos'ta Hellenistik evden figür bezemeli frize ait kısmen birleşebilen parçalar bulunmuştur (resim 10). Buradaki sahneyi Love, bir keçi çevresinde dans eden insanlar olarak yorumlaması nedeniyle "Dans Eden Keçi”li kompozisyon olarak isimlendirilmiştir (Love 1972, 65). Parçanın sağ tarafında mermer taklidi bezeme olması nedeniyle kompozisyon, frizin sağ tarafına ait olmalıdır (Bingöl 1992, 101). Sağlam kalan kısmında en sağdaki figür elini ileri doğru uzatmış bir erkek figürüdür. Figür uzun kollu uzun paçalı dar bir kıyafet giymiş olup sırtında pelerini vardır. Bu figürün işaret ettiği ikinci figür uzun kollu uzun paçalı dar kıyafetinin üzerine mavi tunik giymiş olup hareketli bir şekilde tasvir edilmiştir. İyi durumda korunmamış olmasına karşın üçüncü figürün bir keçinin ön bacaklarından tuttuğu anlaşılmaktadır. Keçi figürü iyi korunmamış ayakta duran bir dördüncü figüre bakmaktadır. Bu figürün arkasında ki figür ise arkalıksız bir sandalyede oturmaktadır. Bu figürün hemen arkasında kısmen korunmuş ayakta duran bir başka figür görülebilmektedir. Oturan figür dışındaki diğer figürlerin Pers giyimli oldukları anlaşılmaktadır. Oturan figür Hellen tarzında omuzları açıkta birakan bir kıyafet giymektedir.

Hellenistik ev figürlü frizi sınırlayan plastik olarak yapılan yumurta dizisi, saç örgüsü ve meander kuşakları, altta ve üstte yer alan duvar örgüsü bezemesi Hellenistik ev duvar resmi 1. Stil özelliğini göstermektedir ${ }^{5}$. Hellen dünyasında 1. Stil de figürlü friz kuşağı olan başka örnekler de bulunmaktadır. Hellenistik Dönem resim sanatında önemli bir yere sahip olan Vergina mezar resimleri arasında Prensin mezarı olarak adlandırılan mezarın resimlerinde benzer şekilde koyu renk zemin üzerinde figürlü bir friz yer almaktadır (Drougou 2005, 169). Benzer şekilde Pergamon'da 4 numaralı sarayın A odasının duvarlarında mimari dekorasyonla birlikte figür bezemeli bir friz yer almaktadır. Burada koyu renk zemin üzerine antitetik duruşlu grifonlar betimlenmiştir. Frizin altında orthostat seviyesinde mermer taklidi bezeme yapılmıştır. Frizin üst kısmında ise yine Knidos örneğiyle benzer şekilde yapılmış üç boyutlu yumurta dizisi yer almaktadır. Yapı M.Ö. 2. Yüzyılın ilk yarısına tarihlenmektedir (Andreou 1988, 125.). Miletos'ta Heroon III'de Hellenistik Döneme tarihlendirilen fresk parçaları ele geçmiştir. Yapılan rekontrüksiyon denemesi sonucunda Grifonlu girland frizini üstte üç boyutlu yumurta dizisi altta örgü motifi sınırladığı görülmektedir. Onların da altında mermer taklidi boyama görülmektedir (Weber 2004, 144.). Benzer şekilde M.Ö. 2. Yüzyıla tarihlenen Delos Komedyenler evinin fresklerinde mermer taklidi bezemenin yanı sıra koyu zemin üzerine yapılmış komedyenlerden oluşan figürlü friz bulunmaktadır (Trümper 1998, 23, 163-164).

Knidos Hellenistik evin fresklerinde Pompeii resim stilleri içerisinde hem plastik hem de boyama olarak yapılmış duvar örgüsüyle 1. Stil kapsamında değerlendirmek gerekmektedir (resim 11). Knidos Hellenistik evin fresklerinde Pompeii 1. Stilden farklı olarak duvar örgüsüne burada figürlü bir friz eşlik etmektedir. Ancak Hellenistik dünyada bu durumun benzer örnekleri mevcuttur. Hellenistik ev freski tarihlendirecek olursak M.Ö. 2. yy 2. Yarıs1 (150-100) demek mümkündür (Love 1971, 6-8).

\footnotetext{
${ }^{5}$ Roma Dönemi duvar resimleri Pompeii freskleri temel alınarak Arkeolog August Mau tarafindan 4 bölümde incelenmiştir. M.Ö. 2. Yüzyılın başlarına tarihlenen Birinci stil genel olarak Hellen duvar işçiliğinin renkli sıvalar ve plastik bordürlerle oluşturulmuş duvar taklididir. Bakınız: Mau 1899, 450-460.
} 


\section{SONUÇ}

Büyük İskender ile başlayıp Hellenistik krallıklar ile devam eden süreçte Akdeniz dünyasında hem siyasal hem kültürel hem ekonomik ve hem de sanatsal olarak büyük bir etkileşim olduğunu söylemek mümkündür. Hellenistik dönem yayıldığı coğrafya bakımından çok geniş bir alana sahip olması sebebiyle kültür açısından zengin ve gelişmiş bir noktaya ulaşmıştır.

Knidos Hellenistik ev örneğinde gördüğümüz üzere Roma resim sanatını açıklamak üzere kullanılan Pompeii stillerinin kaynaklarının kökeni Hellen kültürüne dayanmaktadır. Pompeii 1. Stil hem plastik hem de boyama olarak duvar örgüsü ya da mermer taklidi şeklinde tanımlanmıştır. Knidos örneğinde ve diğer örneklerde de görüldüğü üzere son derece başarılı mimari öğelere örgü, yumurta dizisi, kırık meander gibi bordürler eşlik etmektedir ve ayrıca bunlar son derece başarılı bir şekilde üç boyutlu olarak resmedilmişlerdir. Bu bezeme şemasına figürlü bir frizin eşlik ettiği de görülmektedir. Knidos örneğinde bu frizde mitolojik bir konu üstün bir resim anlayışıyla işlenmiş̧ir.

\section{KAYNAKÇA}

Andreou, A. (1988). Griechische Wanddekorationen, Mainz. Johannes Gutenberg Universität.

Bent, J.T. (1888). "Discoveries in Asia Minor”, Journal of Hellenic Studies 9: 82-7.

Bezerra de Meneses, U.T. (1984). "Essai de lecture sociologique de la décoration murale des maisons d'habitation héllenistiques de Delos". Dial Arch 2, 77-88.

Bingöl, O. (1997). Malerei und Mosaik der Antike in der Türkei. Mainz, Philipp von Zabern.

Bingöl, O. (2009). Hellenistik Dönemde Anadolu. Ankara, Türkiye Kültür Portalı Projesi.

Bruns-Özgan C. (2002). Knidos Antik Kent Rehberi. Konya, Pozitif Matbaacılık.

Doksanaltı, E. M. (2006). Knidos Kap- Krio Kazı Alanı. Selçuk Üniversitesi yayımlanmamış Doktora Tezi.

Doksanaltı, E. M., Karaoğlan, İ. , Tozluca, D. O. (2018). Knidos Denizlerin Buluştuğu Kent. Ankara, Bilgin Kültür Sanat Yayınları.

Drougou, S. - Saatsoglou Paliadeli, Ch. (2005). Vergina: The Land and its History. London, Ephesus Publishing.

Eraslan, Ş. (Yaz 2014). "Roma Dönemi Efes ve Pompeii Duvar Resimlerinin İkonografik Açıdan Değerlendirilmesi”. Yedi: Sanat, Tasarım ve Bilim Dergisi, 12, 1-10.

Kakoulli, I. (2009). Greek Painting Techniques and Materials from the fourth to the first Century BC. London, Archetype Publications.

Love, C. I. (Jan. 1972). “A Preliminary Report of The Excavations at Knidos 1970”. AJA Vol. 76, No. 1, pp. 6176

Love, C. I. (Oct. 1971). “A Preliminary Report of The Excavations at Knidos 1971”. AJA Vol. 76, No. 4, pp. 393-405

Mau, A. (1899). Pompeii Its Life and Art. New York, Mac Millan.

Radt, W. (2017). "Die Ausstattung der Räume von Bau Z mit Stuck und Putz". Altertümer von Pergamon XV, Die Stadtgrabung 5, ed. M. Bachmann ve W. Radt. Berlin, Walter de Gruyter, 207-330.

Tomlinson R.A. (2003). Yunan Mimarlı̆̆ı. Çev: Rıfat Akbulut. İstanbul, Homer Yayınları.

Trümper, M. (2001). "Wohnen in Delos: Eine baugeschichtliche Untersuchung zum Wandel der Wohnkultur in hellenistischer Zeit". Internationale Archaeologie 46. Rahden: Marie Leidorf.

Weber, B.F. (2005). Die Römischen Heroa von Milet, v.10/1, Milet Ergebnisse der Ausgrabungen und Untersuchungen seit dem Jahre 1899, Deutsches Archäologisches Institut. Berlin, Walter de Gruyter.

Yılmaz, N. (2006). "Izgara Tasarlı Kent Gelişimi ve Anadolu Örnekleri”. Atatürk Üniversitesi yayımlanmamış Yüksek Lisans Tezi.

Yılmaz, F. (2008). “Arkaik Dönem Batı Anadolu Resim Sanatı”. Ege Üniversitesi yayımlanmamış Doktora Tezi. 
Yılmaz, F. (2012). “Antik Dönemde Fresk Yapım Teknikleri”. Trakya Üniversitesi Edebiyat Fakültesi Dergisi, Cilt 2. Sayı:4.

\section{EXTENDED ABSTRACT}

The ancient city of Knidos (Fig. 1) is located in the Datça district of Mugla, southwest of Anatolia. It is an important center of Knidos with its structures which have been challenged by the time it has been reached and its Works in many museums. When you go from the port of Knidos, a house that was uncovered in the Hellenic period was uncovered, which is a residential area that is parallel to the Street leading to the remaining terraces. The walls of the house up to 3 meters, are decorated with stucco and plastic sills and painted in a very colorful fresco technique (Fig. 5). The Wall braiding on the orthoptist is limited to the knit motif from the bottom and top. This includes a three-dimensional broken meander band made of yellow, White, Brown colors. The threedimensional meander band has an egg-arrow array of Brown-cream tones on the red floor, which is still made of three dimensions. On top of this, there is a frieze with a figure composition, which is the main embellishment belt of the Wall. Here is a mythological topic depicted on the black background with colorful human figures. This tape limits the knitting motif in Brown-cream shades, which are made in three dimensions again on top. On the boron, the opposite Acanthus (Fig. 6) and the Ranks are depicted with figures such as Eros, Bird, Grasshopper (Fig. 7). The upper part of the frizz is limited to three-dimensional meander border in Brown-cream colors (Love 1971, 6-8). A mythological issue was processed in figure frizz, the main embellishment belt of the Friskin (Fig. 8). Here we describe the training of Achilles by Kenthauros Kherion. In the minds of the composition, the other figures in the vicinity of Achilles and Kherion probably should be the mother of Achilles, Thetis and his father Peleus. Other figures depict the muss. The floor is dark and the figures are made with vivid colors, creating a sense of vitality and a fascinating effect on the human. The presence of other houses with rich decorations on the terrace on the Hellenistic house in Knidos also shows the richness of the period (Bruns-Özgan 2002, 90-91). İ the Knidos, partially combinable parts belonging to the figure decorated fries from the Hellenistic house were found (Fig. 10). Love is named as the "Dancing Goat" essay because it interprets the scene as people dancing around a goat (Love 1972, 65). Although poorly preserved, there is a male figure that holds the anterior verses oh the goat. On the right side of the stage, the figure sitting on a backside stool wears a dress that leaves the shoulders exposed in the style of Helen. Other figures are understood to be long sleeves and long legs with narrow Persian clothing. The Hellenistic house Wall image 1, which is made of plastic as an egg series, brain and meander belts, bordering on the bottom and top, and the Wall braid decoration, which is a part of the Hellenic House figurate frieze. Demonstrates the style property. In the World of Hellen there are also other examples of the style of frieze with figure 1. Among the tomb paintings of Vergina, which has an important place in the art of Hellenistic period, there is a frieze whit a figure on the dark background similarly to the paintings of the tomb called the Tomb of the prince (Drougou 25, 169). Similarly, in Pergamon, there is a room with a figure decorated with architectural decoration on the walls of palace a here, the griffons with antithetic stance on dark ground are depicts. The orthostatic level under the frizzing is made of marble rhinestone embellishment. At the top of the frizzing is the three-dimensional egg array, which is similarly made with the Knidos sample. The structure dates from the first half of the 2nd century BC. (Andreou 1988, 125.). In Miletus the fresco fragments dated to the Hellenistic period were uncovered in Heron III. As a result of the reconstruction attempt, the three-dimensional egg array on the top of the griffon most is seen to limit the knitting motif at the bottom. They are also seen under the marble imitation painting (Webwr 2004, 144.). similarly, Delos comedians dating to the 2nd century BC. Have a figurines of marble imitations in the frees of the house, as well as a figure frieze consisting of comedians made on dark ground (Trümper 1998, 23, 163-164). İn the frescos of the Hellenistic house, Knidos was created in Pompeii painting styles whit a tapestry made of both plastic and painting in 1. The style should be evaluated under the scope (Fig. 11). Knidos in the frescos of the Hellenistic house Pompeii 1. Unlike the style the Wall is accompanied by a frizz that is figurate here. However, there are similar examples of this situation in the Hellenistic World. To date the Hellenistic house fresco BC 2nd century 2. Half (150-100) is possible to say (Love 1971, 6-8). 


\section{RESIMLER}

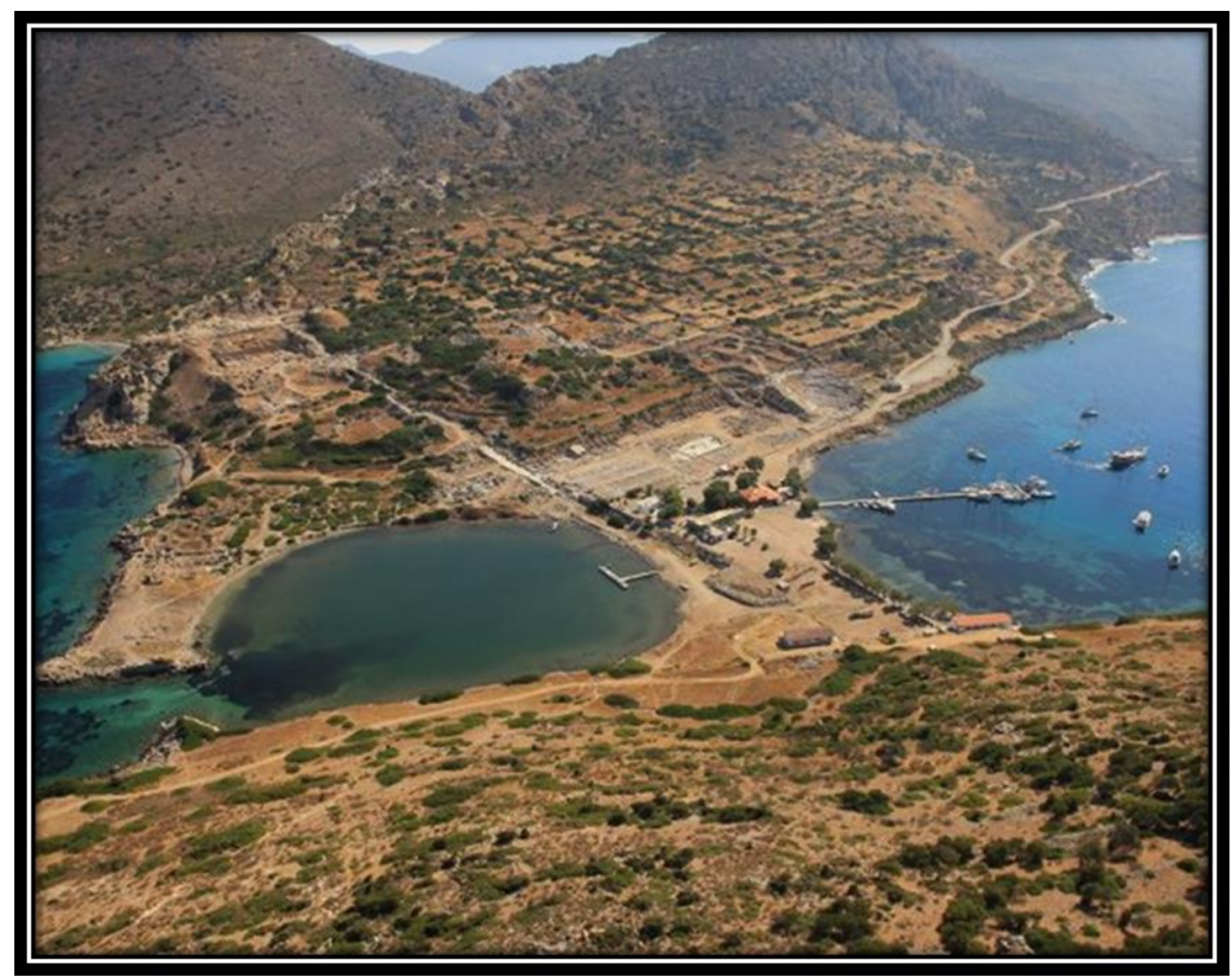

Resim 1: Knidos Antik Kenti havadan görünümü 


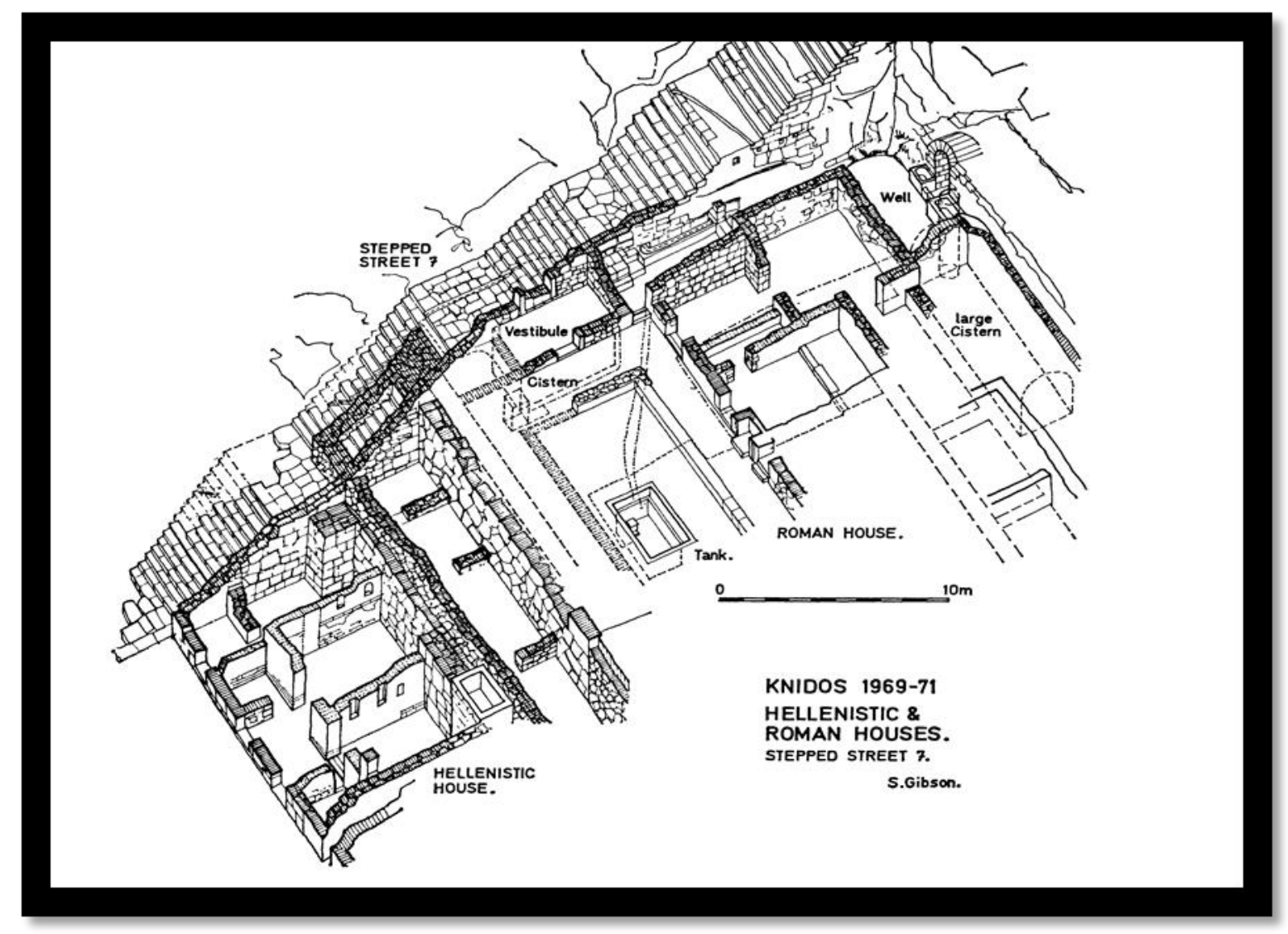

Resim 2 :Hellenistik ev (I.C. Love tarafından çizilen) 


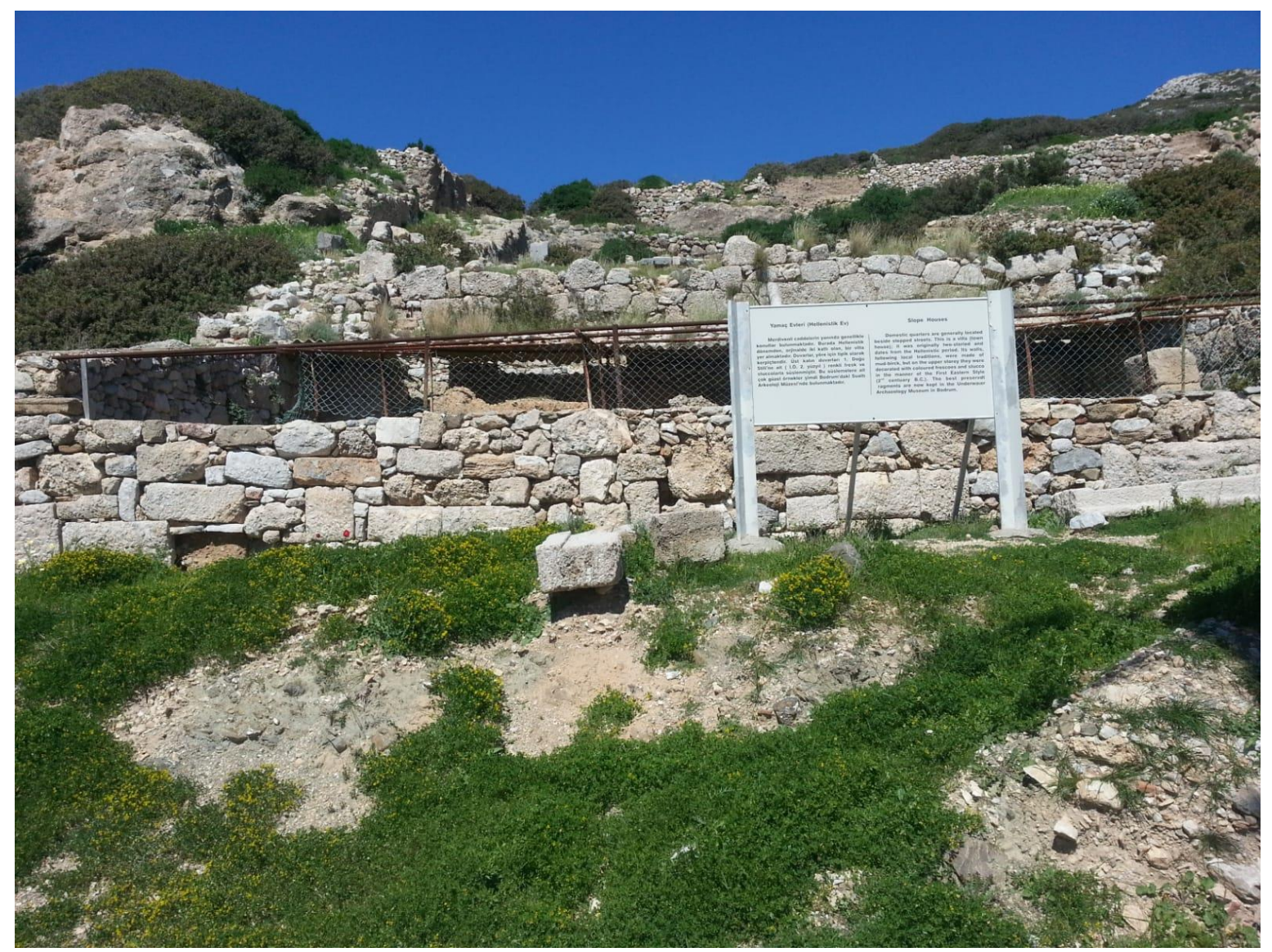

Resim 3: Knidos Hellenistik ev havadan görünümü (Günümüzde koruma çatısı altında)

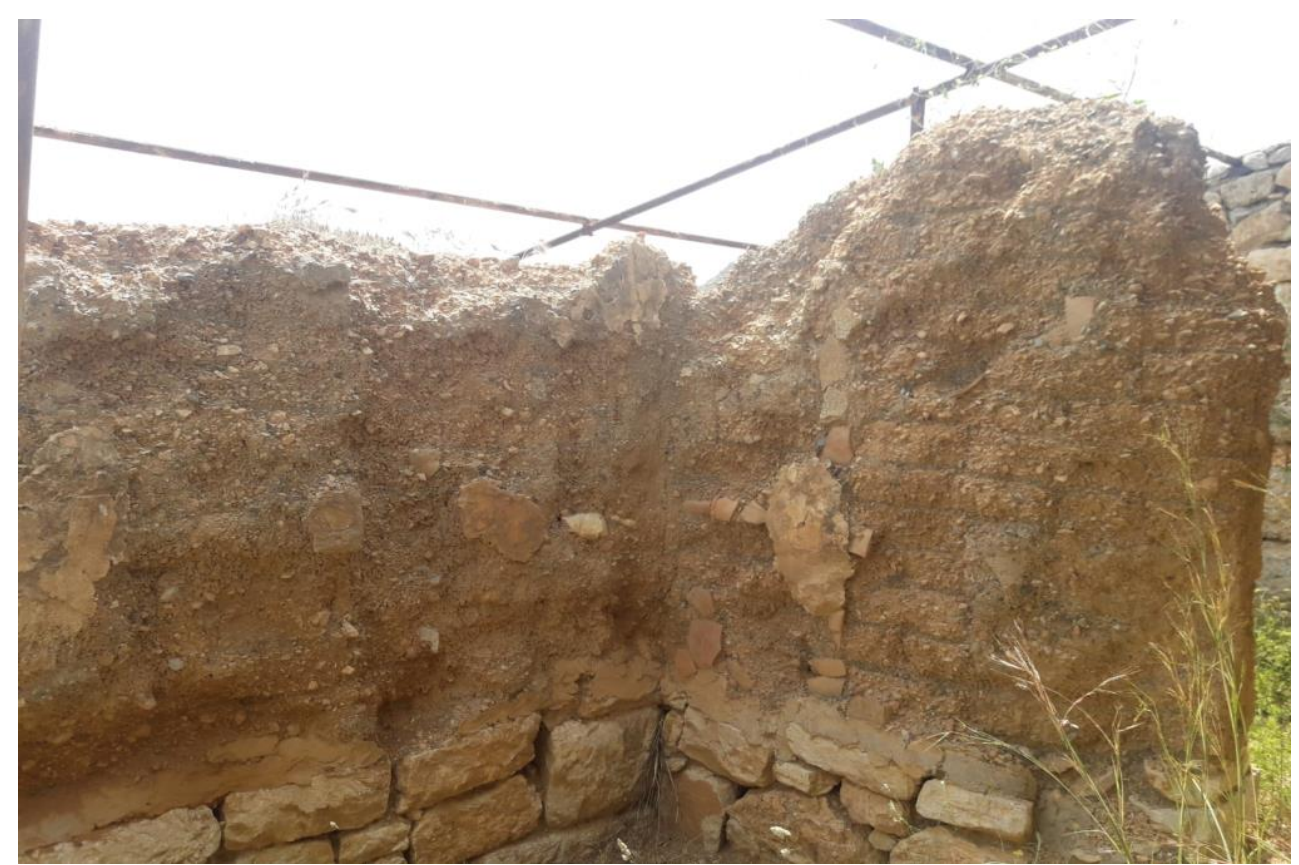

Resim 4: Hellenistik ev konglomere ve mermer temeller ve üstüne yükselmekte olan kerpiç duvarlar. 


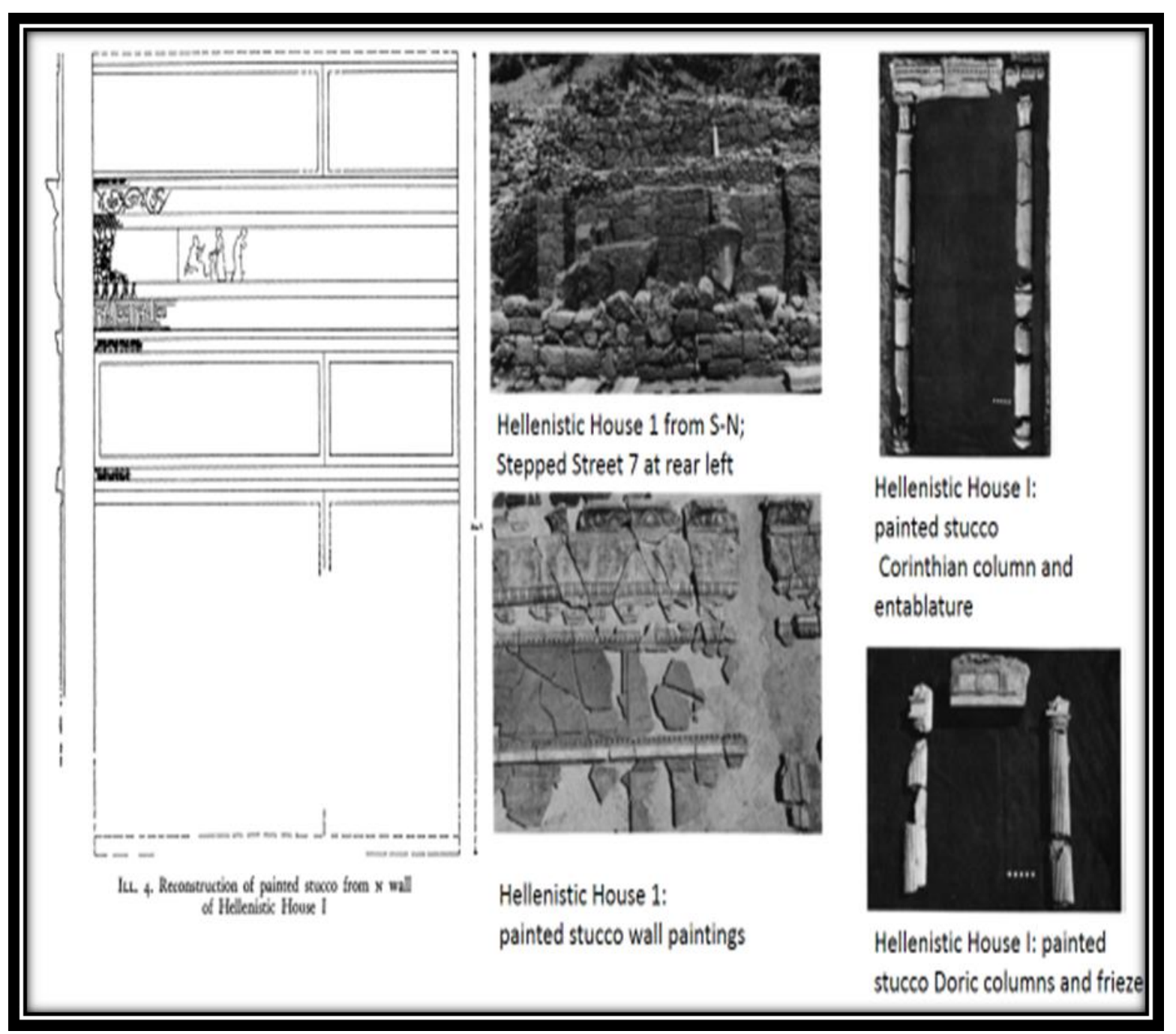

Resim 5: I. C. Love tarafından çizilmiş olan freskin rekonstrüksiyonu, stükko dorik ve korinth sütunlar, freskten bazı parçalar ve Hellenistik evin Güney-Kuzey yönlü fotosu 


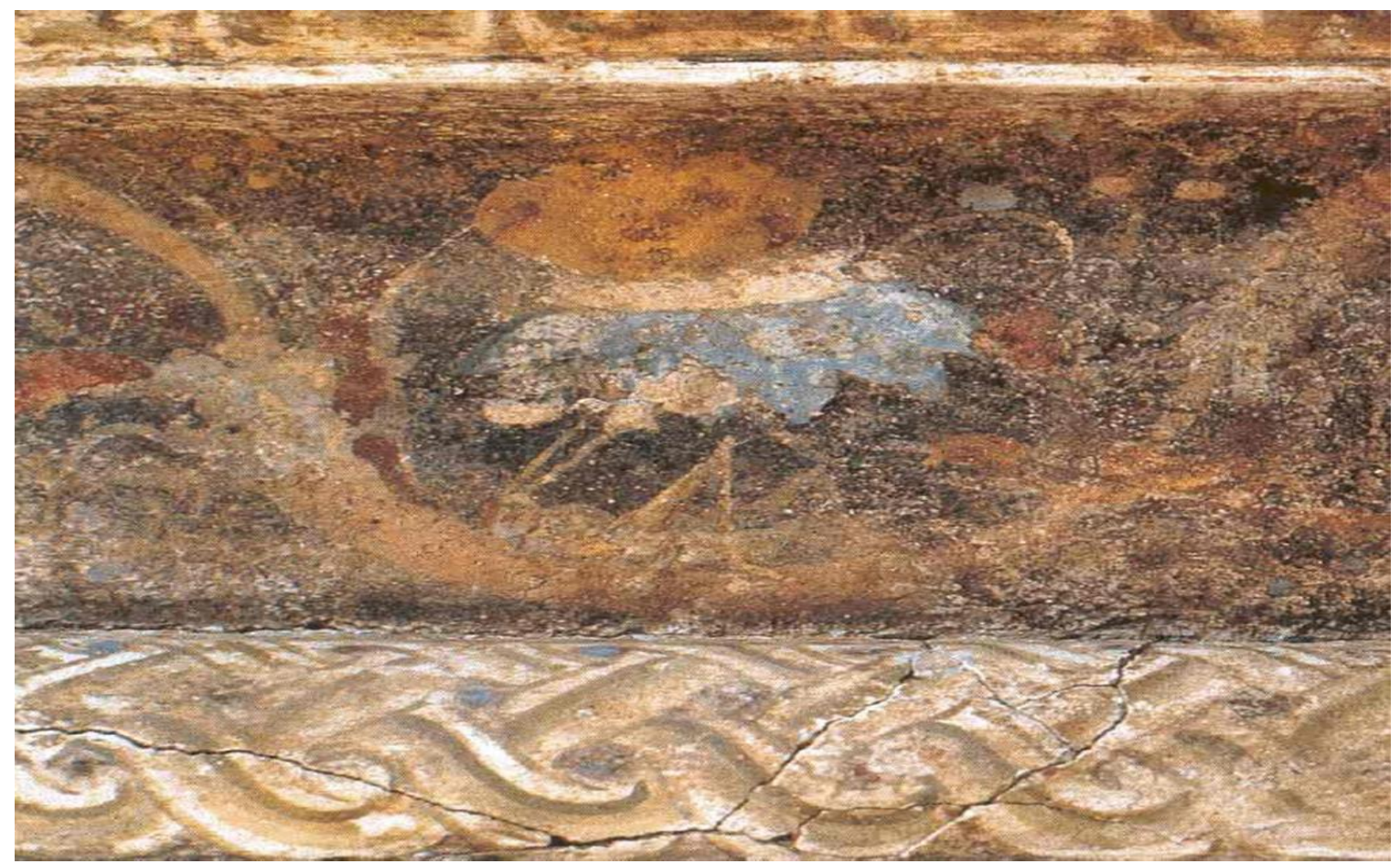

Resim 6: Meander, ters akantüs, çekirge ve örgü motifi

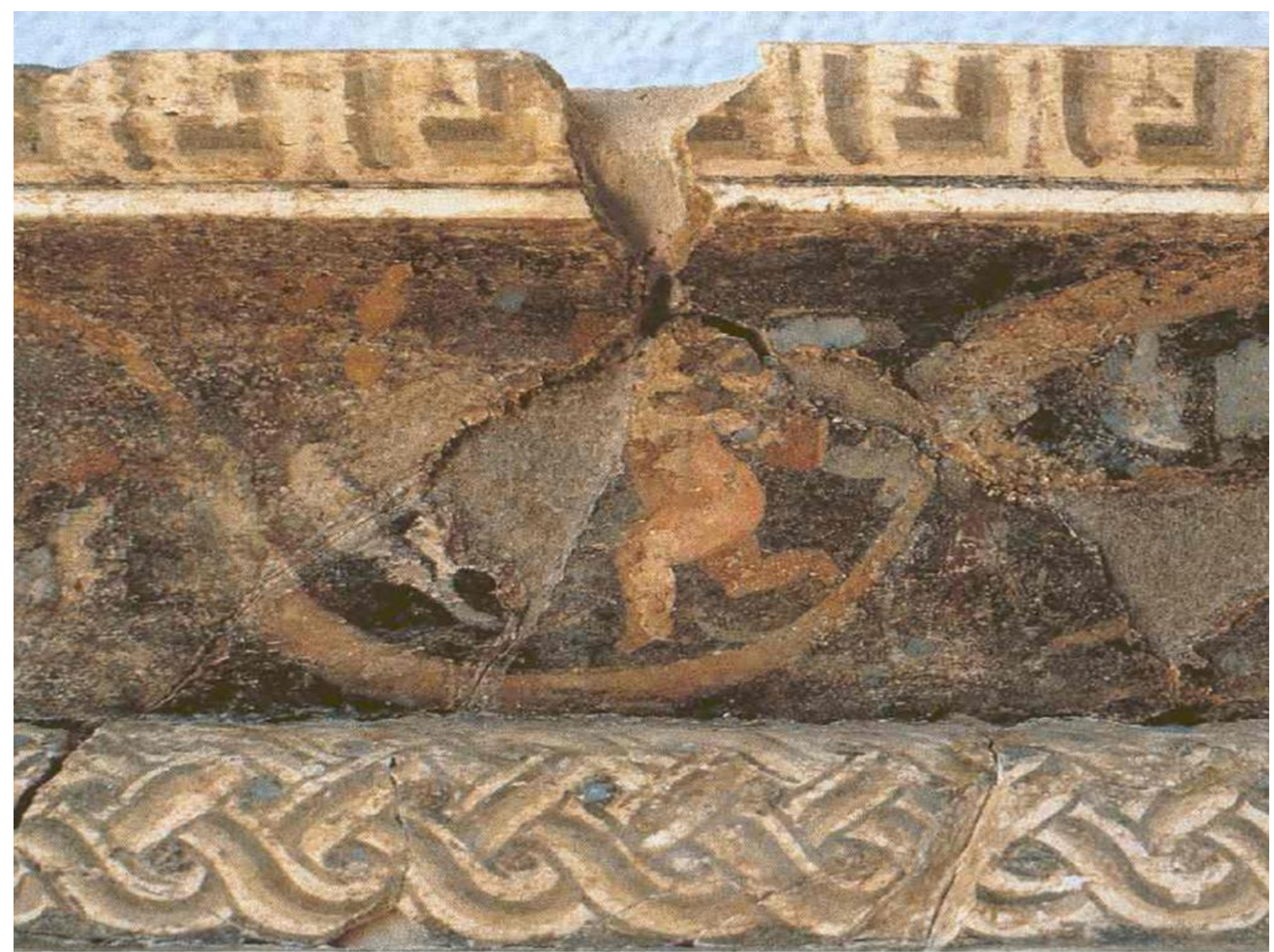

Resim 7: Meander, rankeler arasında eros, bitki motifleri ve giyoş motifi 


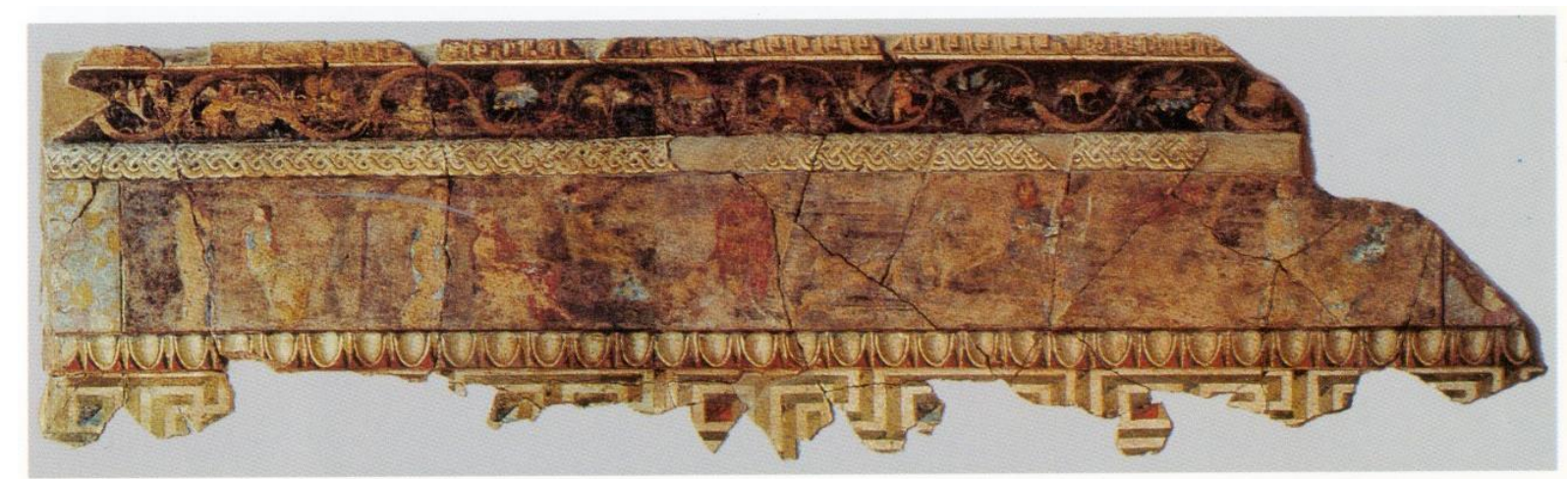

Resim 8: Mitolojik konun işlendiği figür bezemeli friz.

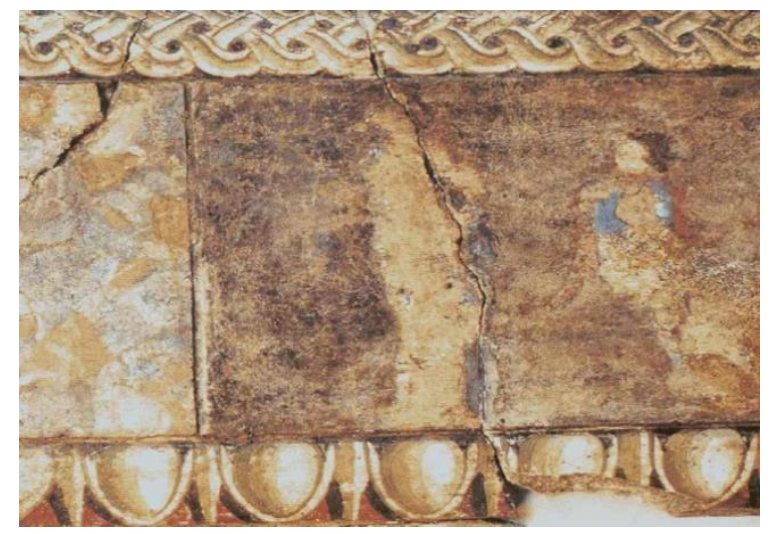

Resim 9: Mitolojik konun işlendiği figür bezemeli friz detay.

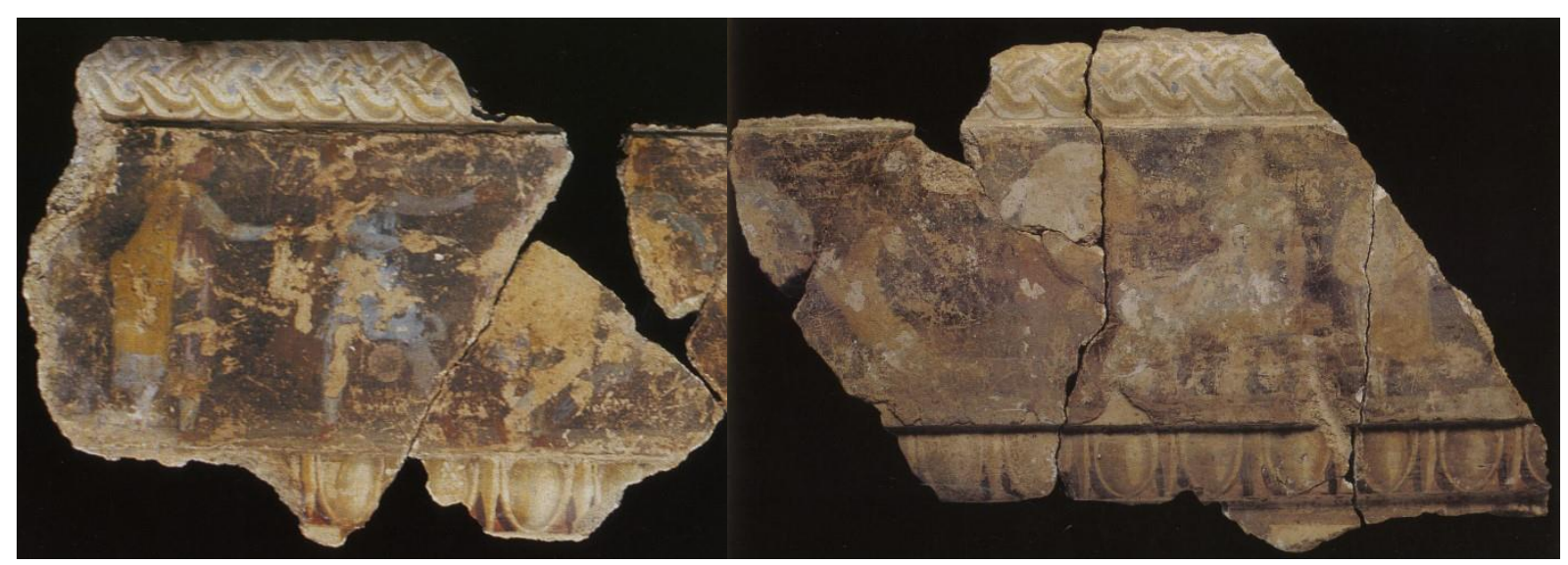

Resim 10: "Dans eden keçili kompozisyon” isimli figürlü bezeme frizi. 


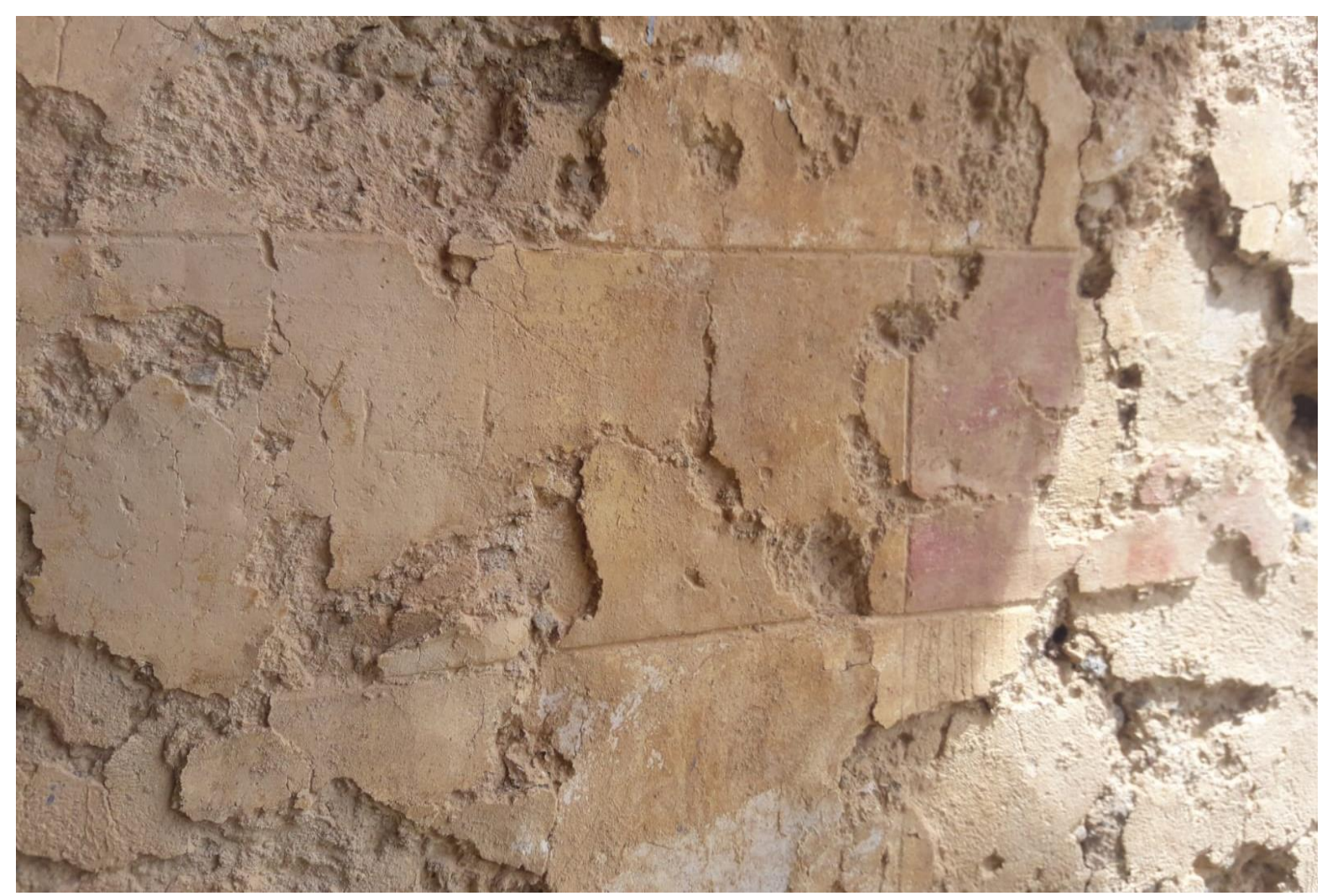

Resim 11:Boyama ve kazı olarak yapılmış duvar örgüsü taklidi. 